\title{
Lobomycosis post long-term corticosteroid therapy: a case report
}

\author{
Lobomicose pós-terapia com corticosteroide de longo prazo: relato de caso \\ Lobomicosis después de la terapia con corticosteroides a largo plazo: reporte de un caso
}

Received: 12/18/2021 | Reviewed: 12/23/2021 | Accept: 01/02/2022 | Published: 01/03/2022

\author{
Herman Saputra \\ ORCID: https://orcid.org/0000-0003-1460-3884 \\ Faculty of Medicine Udayana University Sanglah Public Hospital, Indonesia \\ E-mail: herman_saputradps@yahoo.com \\ Ni Putu Sriwidyani \\ ORCID: https://orcid.org/0000-0002-6910-9472 \\ Faculty of Medicine Udayana University Sanglah Public Hospital, Indonesia \\ E-mail: sriwidyani@unud.ac.id \\ Putu Erika Paskarani \\ ORCID: https://orcid.org/0000-0003-2869-9071 \\ Faculty of Medicine Udayana University Sanglah Public Hospital, Indonesia \\ E-mail: erika_paskarani@unud.ac.id \\ Tanaka \\ ORCID: https://orcid.org/0000-0002-0186-5802 \\ Faculty of Medicine Udayana University Sanglah Public Hospital, Indonesia \\ E-mail: tanaka@student.unud.ac.id
}

\begin{abstract}
Introduction: Lobomycosis is one of the most rarely reported fungal infections worldwide. Most reported cases of lobomycosis is endemic in Central and South America, especially around Amazon. The affected body areas usually the ears, lower extremities, upper extremities, face, chest, and back. Objective: to present the course of lobomycosis post long-term corticosteroid therapy. Methodology: Descriptive study of the case report type, whose data were obtained from the patient's medical record. Case presentation: This paper reports a 23-year-old woman, who suffered wounds which almost covered almost all of her body surface without any fever. On physical examination, multiple ulcers were found with maceration of the wound edges and multiple reddish bumps in the anterior and posterior trunk regions. There is no appearance of keloids. The patient had a history of pemphigus vulgaris and pemphigus vegetans and was receiving long-term corticosteroid therapy. The microbiological examination did not reveal any fungal growth. Histopathological examination of the tissue with Hematoxylin-Eosin and Periodic Acid Schiff (PAS) staining confirmed diagnosis of lobomycosis. Conclusion: Based on clinical and laboratory findings, the patient was diagnosed with Lobomycosis.
\end{abstract}

Keywords: Jorge Lobo's Disease (Lobomycosis); Young woman; Long term corticosteroid therapy.

\section{Resumo}

Introdução: A lobomicose é uma das infecções fúngicas mais raramente relatadas em todo o mundo. A maioria dos casos relatados de lobomicose é endêmica na América Central e do Sul, especialmente em torno da Amazônia. As áreas do corpo afetadas geralmente são as orelhas, extremidades inferiores, extremidades superiores, rosto, tórax e costas. Objetivo: apresentar a evolução da lobomicose após corticoterapia de longa duração. Metodologia: Estudo descritivo do tipo relato de caso, cujos dados foram obtidos no prontuário do paciente. Apresentação do caso: Este artigo relata uma mulher de 23 anos, que sofreu feridas que cobriam quase toda a superfície do corpo sem qualquer febre. Ao exame físico, foram encontradas múltiplas úlceras com maceração das bordas da ferida e múltiplas saliências avermelhadas nas regiões anterior e posterior do tronco. Não há aparecimento de quelóides. O paciente tinha história de pênfigo vulgar e pênfigo vegetante e estava em uso de corticoterapia por longo prazo. O exame microbiológico não revelou crescimento de fungos. $O$ exame histopatológico do tecido com coloração de Hematoxilina-Eosina e Ácido Periódico de Schiff (PAS) confirmou o diagnóstico de lobomicose. Conclusão: Com base nos achados clínicos e laboratoriais, o paciente foi diagnosticado com Lobomicose.

Palavras-chave: Doença de Jorge Lobo (Lobomicose); Mulher jovem; Corticoterapia de longa duração.

\section{Resumen}

Introducción: La lobomicosis es una de las infecciones fúngicas notificadas con menor frecuencia en todo el mundo. La mayoría de los casos notificados de lobomicosis son endémicos en América Central y del Sur, especialmente alrededor de la Amazonía. Las áreas del cuerpo afectadas suelen ser las orejas, las extremidades inferiores, las extremidades superiores, la cara, el pecho y la espalda. Objetivo: presentar la evolución de la lobomicosis tras la terapia con corticosteroides a largo plazo. Metodología: Estudio descriptivo del tipo de reporte de caso, cuyos datos se 
obtuvieron de la historia clínica del paciente. Presentación del caso: En este trabajo se informa a una mujer de 23 años, que sufrió heridas que casi cubrieron casi toda la superficie de su cuerpo sin fiebre. Al examen físico se encontraron múltiples úlceras con maceración de los bordes de la herida y múltiples protuberancias rojizas en las regiones anterior y posterior del tronco. No hay aparición de queloides. El paciente tenía antecedentes de pénfigo vulgar y pénfigo vegetante y estaba recibiendo tratamiento con corticosteroides a largo plazo. El examen microbiológico no reveló ningún crecimiento de hongos. El examen histopatológico del tejido con tinción con hematoxilina-eosina y ácido periódico de Schiff (PAS) confirmó el diagnóstico de lobomicosis. Conclusión: Con base en los hallazgos clínicos y de laboratorio, el paciente fue diagnosticado de Lobomicosis.

Palabras clave: Enfermedad de Jorge Lobo (Lobomicosis); Mujer joven; Terapia con corticosteroides a largo plazo.

\section{Introduction}

Lobomycosis is a chronic granulomatous infection of the cutis and subcutis caused by the fungal species Lacazia loboi (Arju et al., 2014; de Sousa et al., 2015; Grayson \& Colonje, 2020; Hall et al., 2017; Pasqualotto et al., 2021; Queiroz-Telles et al., 2017). This disease is endemic to tropical forest areas of Central and South America, particularly in the Amazon basin, (Grayson \& Colonje, 2020) and cases are very rarely reported outside this area (Beltrame et al., 2017). As many as 58.5\% of the 550 cases that have been reported worldwide came from Brazil (Florian et al., 2020). However, cases of lobomycosis have also been reported in the United States, North America, Africa, and Southeastern Europe (Grayson \& Colonje, 2020; Papadavid et al., 2012).

It is believed that environmental factors play a role in the risk of this lobomycosis fungal infection (Arju et al., 2014). For cases outside endemic areas, imported cases of lobomycosis were associated with an increase in the number of international visits to endemic areas (Beltrame et al., 2017). However, in 2008 South Africa was diagnosed in a patient with no travel history to a known endemic area (Oliveira et al., 2020). This is a quite difficult and rare cases. It needs a comphrehensive understanding of clinicopathological for establishing diagnosis. We reported a lobomycosis infection which focusing on pathological aspect.

\section{Methodology}

This is a descriptive study of the case report type. In general, case study research is centered on a phenomenon, which is described in as much depth as possible (Yin, 2017; Pereira et al., 2018). Analysis of the medical record for description of the clinical case, being presented in chronological order, and literature review using scientific databases. Our research ethics committee did not conduct any ethical clearance for the case report due to its already discussed at the clinicopathological conference and approved by the clinician, patient, and pathologist. Following ethical principles, the patient consented to disseminating the data and displaying images of his case for academic purposes through the signing of a Free and Informed Consent Form.

\section{Case Report}

The patient had history of skin biopsy when she was 19 years old. She had undergo biopsy due to vesicles on the lef brachial region and nodules in the right inguinal region. At that time, microbiological examination showed isolated MRSA bacteria, namely Pseudomonas stutzeri and Staphylococcus aureus at the wound area. The left brachial vesicles biopsy showed suprabasal bullae and acantholysis with few distribution of inflammatory cells of lymphocytes and neutrophil PMNs which morphologically diagnosed as pemphigus vulgaris lesion (picture A and B). The right inguinal nodule revealed acanthotic epidermal layers and forms a verrucous structure and morphologically diagnosed as pemphigus vegetans (picture $\mathrm{C}$ and $\mathrm{D}$ ). She hospitalized due to complicated infection for 2 weeks. 
Figure 1. Microscopic findings. A,B. Suprabasal bullae and loss of cohesion between keratinocytes with few lymphocytes and neutrophil PMNs. C,D The epidermis appears acanthotic and forms a verrucous structure.
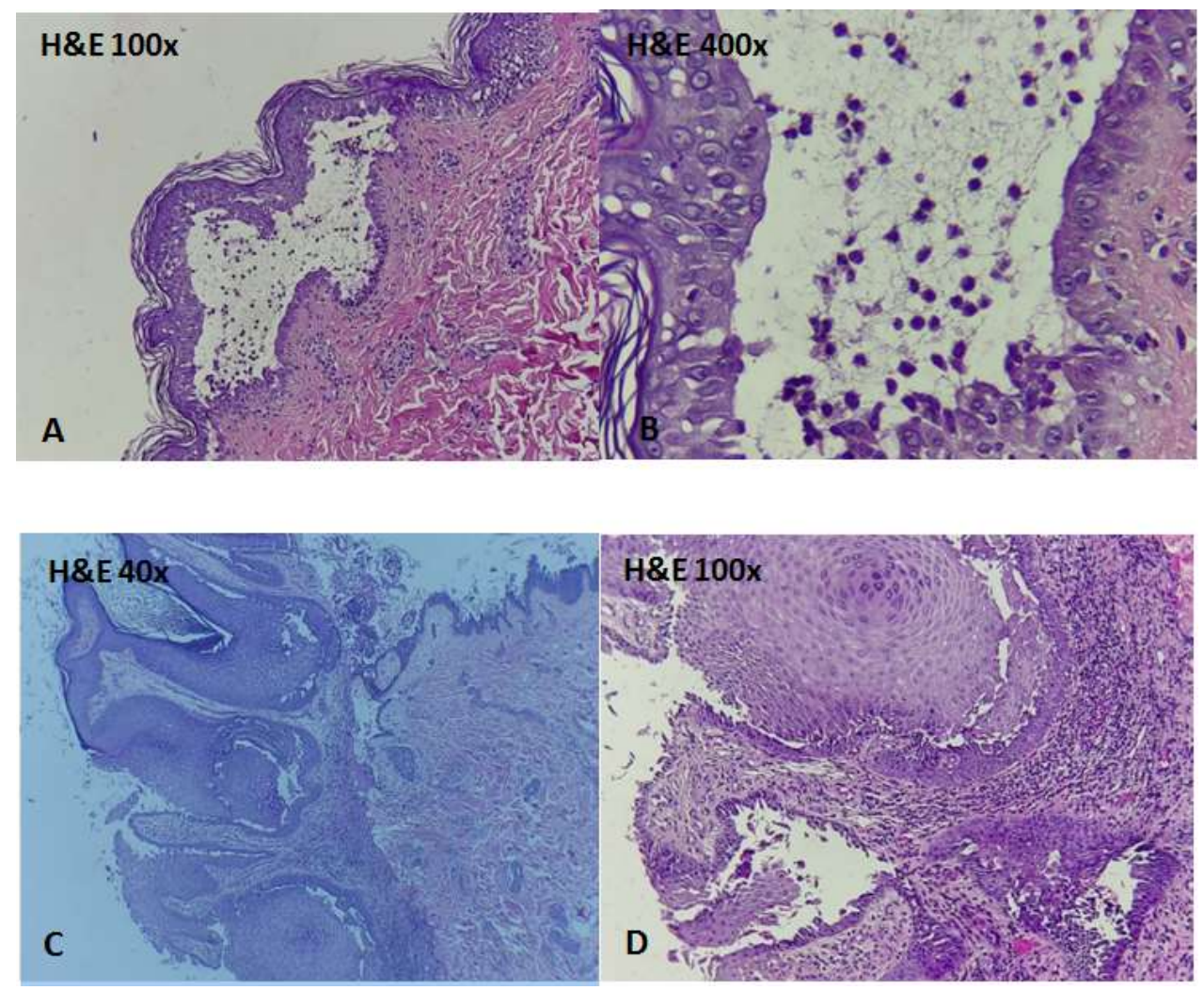

Source: Authors.

Now, she was 23 years old and hospitalized due to pain in cause by wounds which cover all over her body without fever. The wound appears at stomach and back region since three months ago. At first its only redness all over the body and later accompanied by bubbles filled with fluid with pain and heat. Patient had history of methylprednisolone therapy since she was 19 years old and diabetes mellitus since 3 months before admission to hospital.

Physical examination found multiple ulcers with bullous striae and multiple reddish lumps on anterior trunk (Figure A) and multiple ulcers in posterior trunk (Figure B). In the right and left upper and lower extremity region, multiple crusts were seen, multiple crusts and pus were seen. The Clinical Pathology laboratory examination results on April 15, 2021, showed complete blood counts within normal limits and current blood glucose levels of $323 \mathrm{mg} / \mathrm{dL}$ (70-140 mg/dL). The Clinical Pathology laboratory examination results on April 18, 2021, showed albumin $2.91 \mathrm{~g} / \mathrm{dL}$ (3.40-3.80 g/dL). 
Figure 2. Clinical examination. A. The anterior trunk region showed multiple ulcers with a subcutaneous base with necrotic tissue, maceration of the wound edges, active bleeding, and bullous striae. B. In the posterior trunk region, multiple ulcers with a subcutaneous base were seen with necrotic tissue, maceration of the wound edges, and inactive bleeding.

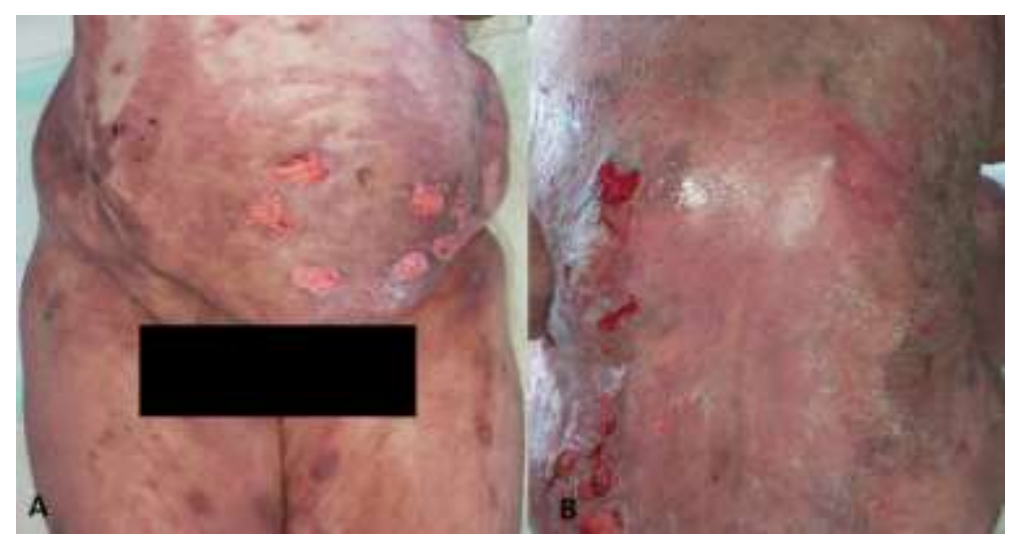

Source: Authors.

The results of the microbiological examination on April 16, 2021, were based on isolated wounds of Klebsiella oxytoca and Escherichia coli bacteria. Microbiological examination results dated April 21, 2021, on the wound bed isolated from MRSA (Methycillin Resistant Staphylococcus aureus) bacteria and isolated pus specimens of Streptococcus agalactiae bacteria.

Resection of ulcerated abdominal skin and abdominal skin with necrotic tissue was performed and sent to pathology laboratory. The first container was 'the right abdomen' contained one piece of tissue measuring $1 \times 0.2 \times 0.1 \mathrm{~cm}$, covered with skin measuring $1 \times 0.2 \times 0.1 \mathrm{~cm}$, elongated shape, white-grey colour, fleshy consistency. All processed in 1 cassette. The second container was 'the left abdomen' contains two pieces of tissue. The first tissue size was $0.9 \times 0.6 \times 0.3 \mathrm{~cm}$ covered with skin $0,9 \times 0,6 \times 0,1 \mathrm{~cm}$, and the second was $0.7 \times 0.7 \times 0.4 \mathrm{~cm}$ with no visible skin, irregular shape, white-grey colour, fleshy consistency. All processed in 1 cassette.

Figure 3. Macroscopic Appearance of Resection of Ulcerated Abdominal Skin.

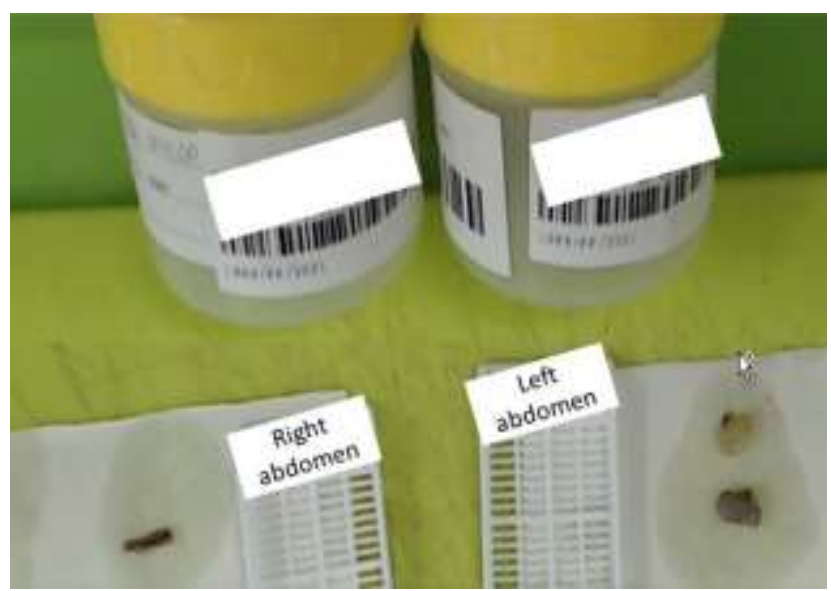

Source: Authors.

On initial routine histopathological microscopic examination and Periodic Acid Schiff (PAS) histochemical staining on ulcerated abdominal skin, the tissue sections were covered with skin. In the epidermal layer, surface epithelial discontinuities and acanthosis appear. In the dermis layer, epithelioid histiocytes appear to form a granuloma structure with the distribution of multinucleated giant cells, the distribution of mixed inflammatory cells (neutrophilic PMN and 
lymphoplasmacytic cells), and fibrosis and necrotic debris in between. There were focal chains, tetrad, and sieve-like appearance of yeast with thick-walled spores of 6-12 micrometers that were refractile and intracellular and extracellular.

Histopathological revealed, acanthotic verrucous at the epidermis layer (Figure 4A) and the dermis layer showed epithelioid histiocytes appear to form a granuloma structure with the distribution of multinucleated giant cells, the distribution of mixed inflammatory cells (neutrophilic PMN and lymphoplasmacytic cells), and fibrosis and necrotic debris in between (Figure 4B). Fungal infection with chain, tetrad, and sieve-like foci appear on hematoxylin and eosin stain (Figure 4C) and confirmed by PAS histochemical staining appear bright red with ring shape confirmed the appearance of yeast with thickwalled spores with a size of 6-12 micrometers, refractile and both intracellular and extracellular (Figure 4D). Based on histopathological findings supported the diagnosis of lobomycosis.

Figure 4. Microscopic Appearance. A. The epidermis layer appeared to be verrucous acanthotic (red arrow). B. The dermis layer appeared to be epithelioid histiocytes forming a granuloma structure with the distribution of multinucleated giant cells and mixed inflammatory cells (neutrophilic PMN and lymphoplasmacytic cells) and fibrosis and necrotic debris in between (blue arrows). C,D. Chain, tetrad, and sieve-like foci appear with the appearance of yeast with thick-walled spores with a size of 6-12 micrometers, refractile and intracellular and extracellular (black arrows).
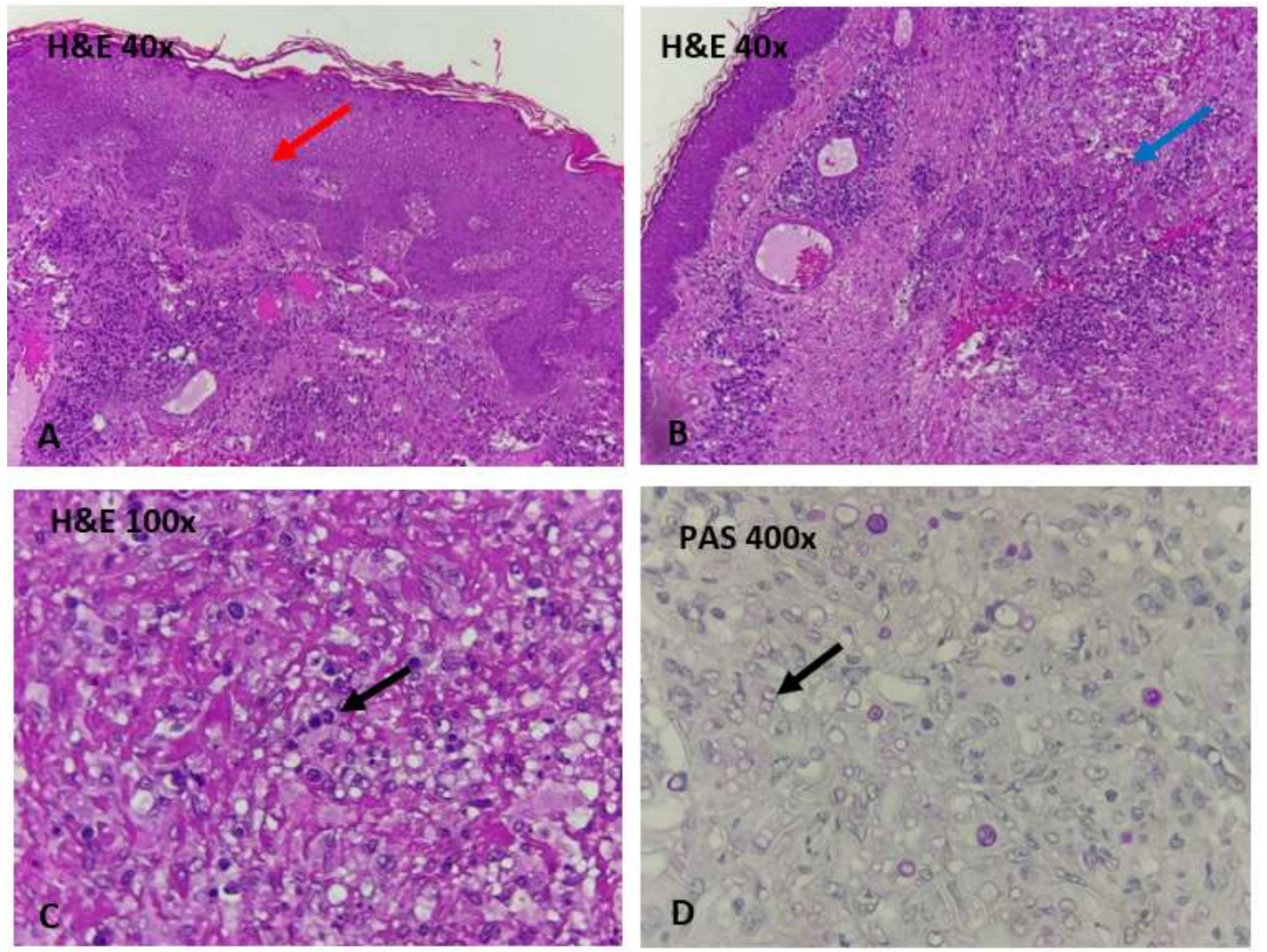

Source: Authors.

\section{Discussion}

Lobomycosis or Lacaziosis or Jorge Lobo's disease or Keloidal Blastomycosis, or Amazonic Blastomycosis, is a chronic granulomatous infection of the cutis and subcutis caused by the fungal species L. loboi (formerly Loboa loboi and Paracoccidioides loboi) that can infect humans and dolphins (Arenas et al., 2019; Arju et al., 2014; de Sousa et al., 2015; Francesconi et al., 2014; Grayson \& Colonje, 2020; Hall et al., 2017; Pasqualotto et al., 2021; Queiroz-Telles et al., 2017). Dermatologist Jorge Lobo first discovered Lobomycosis in Recife, Brazil, in 1931 (Grayson \& Colonje, 2020). The natural 
reservoir of L. loboi is unknown, but it is suspected that there are relationships with soil, vegetation, and aquatic environments. Lobomycosis transmission is thought to occur through trauma, inoculation, or insect bites (Araújo et al., 2018; Arju et al., 2014). The prevalence of this disease is low (de Sousa et al., 2015). Lobomycosis in humans has been reported in only about 500 cases and is very rare outside Central America and South America (Beltrame et al., 2017). The age range of lobomycosis sufferers is quite broad, namely between the ages of 12-70 years, and is dominated by males (Hall et al., 2017).

It is believed that the role of environmental factors (environmental exposure) plays a more critical role in the risk of this fungal infection, (Arju et al., 2014) including the tendency for men to be more infected with lobomycosis than women due to the greater risk of exposure to the environment in men (Arenas et al., 2019). In Florian's study, 2020, it was stated that Kaiabi tribal women in Brazil turned out to have a high enough prevalence to experience lobomycosis due to activities in close contact with the environment, and most cases had early disease onset since the age of $<21$ years with the youngest age one year due to premature contact on wood and soil (Florian et al., 2020). Due to the relatively slow and insidious onset of the disease and the wide variety of clinical manifestations, the diagnosis of this disease often lags behind the time of exposure (Arju et al., 2014; de Sousa et al., 2015).

The risk factors for a person to be infected with lobomycosis are skin inoculation, especially on parts of the skin that are easily exposed to the environment, a history of being pierced by sharp objects, insect bites, exposure to the aquatic environment, direct or indirect contact with dolphins or a history of traveling to endemic areas (Arju et al., 2014; Beltrame et al., 2017; Kanashiro-Galo et al., 2020). Related to immunocompromised conditions, Reif et al., 2009 in Papadavid, 2012 stated that lobomycosis in immunocompromised conditions could be an opportunistic infection (Papadavid et al., 2012). However, this is still not enough to prove its correlation.

This fungus is an obligate intracellular pathogen found in macrophage vacuoles and reproduces by budding, forming linear chains, and branching cell walls containing melanin (Araújo et al., 2018). When these fungal cells infect humans, the human cellular immune response will be more activated in the form of macrophage activity and the expression of cytokine transforming growth factor - (TGF)- $\beta$. High expression of TGF- $\beta$ cytokines, inhibition of nitric oxide expression, and low levels of interferon (IFN)- $\Upsilon$, suppress macrophage lytic activity resulting in a less responsive cellular immune response, leading to antigen-specific cell-mediated immune deficiency and inducing fibrosis (contributing to the emergence of keloid lesions). Lack of Th1 response related to Th17 cytokine production results in the persistence of this fungus (Araújo et al., 2018; Arenas et al., 2019; Arju et al., 2014; Kanashiro-Galo et al., 2020; Papadavid et al., 2012). In nodular lesions, the cellular components that produce immune response cells are more active, whereas, in infiltrative keloids and wart-like lesions and disseminated lesions, immune response cells appear less active (Arenas et al., 2019). On PAS staining, macrophages contain a large amount of PAS-positive granular material that appears to consist of fungal capsule fragments, indicating that the host macrophages cannot digest glycoproteins in the capsule (Hinshaw \& Longley, 2015). Lobomycosis in humans is more associated with decreased cellular immune response than humoral immune response (Arju et al., 2014).

There are no systemic manifestations of lobomycosis (Oliveira et al., 2020). The disease is generally asymptomatic, (Hay, 2020; Hinshaw \& Longley, 2015) but symptoms of pruritus, burning, hypoesthesia, or anesthesia may also occur (Grayson \& Colonje, 2020). The lesions present are highly variable, and patients can have $>1$ type of lesion (Florian et al., 2020). The lesions found include wart-like, nodules, papules, macules, gummas, scleroderma, infiltrates or scars, keloid-like nodules, plaques, verrucous, or ulcerations (Araújo et al., 2018; Arju et al., 2014; Francesconi et al., 2014; Hall et al., 2017; Hinshaw \& Longley, 2015; Queiroz-Telles et al., 2017). Keloid-like nodules and verrucous lesions are the most common. Localized lesions may progress to disseminated disease through the contiguous spread of the disease and via the lymphatic pathway (Oliveira et al., 2020).

Examinations that can be performed to determine the diagnosis of lobomycosis are direct microscopic examination to 
assess the presence of fungi and histopathological examination through tissue biopsy (Araújo et al., 2018; Hay, 2020). Fungal cells can be found in the dermis and epidermis layers, significantly often found in the stratum corneum (Kanashiro-Galo et al., 2020). The dermis layer and the epidermis layer are separated by a green zone (Hinshaw \& Longley, 2015). The surface layers of the epidermis are generally attenuated, although vegetative lesions are associated with hyperplasia and hyperkeratosis (Grayson \& Colonje, 2020). Epidermal layers appear flat, atrophic, acanthotic, and pseudoepitheliomatous hyperplasia. The dermis layer presents with diffuse nonnecrotizing granulomatous inflammation consisting of foreign bodies, fungus-containing foamy histiocytes, asteroid bodies, lymphocytes, macrophages, and characteristic thick-walled yeast-containing multinucleated giant cells. Plasmacytic and neutrophilic infiltrates are also seen in ulcerated lesions (Grayson \& Colonje, 2020; Hall et al., 2017; Patterson, 2013; Plaza \& Prieto, 2012). In addition, lymphocytes can also be found that spread with plasma cells. Fungal spores are seen between and outside these cells (Hinshaw \& Longley, 2015). Fibroblasts can be seen surrounding the keloid lesion. No suppurative inflammation and necrosis were seen.

The morphological diagnostic criteria of Lacazia spp. On examination of the biopsy specimen, the organisms are spherical, yeast-like with a diameter of 6-12 $\mu \mathrm{m}$ (usually 9-10 $\mu \mathrm{m}$ ), refractile, singly or in long chains of round and hyaline cells, connected by thin and short tubular links with thick and branched cell walls. (rosary-shaped or dumbbell-shaped) (Arju et al., 2014; Beltrame et al., 2017; Carvalho et al., 2015; Grayson \& Colonje, 2020; Hall et al., 2017). Elsayed et al., 2004 in Arju, R. 2014 stated that only L. loboi is the only fungus that forms chains of fungal cells of uniform size, 6-12 $\mu \mathrm{m}$ in diameter, which is connected by thin tubular links (Arju et al., 2014). The cytoplasm is transparent and with a thick wall (clear cell appearance), creating a "sieve-like appearance" in granulomatous inflammation (Arju et al., 2014; Patterson, 2013; Plaza \& Prieto, 2012). In heavily infected lesions, the skin adnexa and nerves may be damaged, and this condition may clinically resemble leprosy (Grayson \& Colonje, 2020).

The staining that is commonly done in the examination of lobomycosis is Hematoxylin-Eosin, but in this staining, the fungal cells are not stained easily (Grayson \& Colonje, 2020). Specific staining that can be done is with PAS staining (thick capsule appears, with a thickness of about $1 \mathrm{~mm}$ with a tip (lemon-like appearance) (Hinshaw \& Longley, 2015). On examination of fungal culture, no fungal growth was found. Elsayed et al., 2004 in Arju R, 2014 stated that only L. loboi was the only fungus that could not grow in vitro in the existing routine fungal culture media because breeding is difficult to do with very slow fungal growth (Arju et al., 2014).

The differential diagnosis of lobomycosis includes keloids, lepromatous leprosy, verrucous cutaneous leishmaniasis, and other skin mycoses, namely blastomycosis, cryptococcosis, sporotrichosis, chromoblastomycosis, paracoccidioidomycosis, and African histoplasmosis (Beltrame et al., 2017). Leishmaniasis microscopically appears as an oval-shaped organism with a size of 2-4 m, which is characterized by a Giemsa stain that displays a pink-red or purple color in the nucleus and kinetoplast. It is important to note that this organism is not stained with Grocott Methenamine Silver stain or PAS (Hinshaw \& Longley, 2015). Blastomycosis/North American blastomycosis caused by Blastomyces dermatitidis with microscopic yeast-like bodies have broad-based budding spores single or multiple and thick-walled (double-contoured appearance) with a size of 8-15 $\mu \mathrm{m}$ located between multinucleated giant cells. Cryptococcosis caused by C. neoformans has microscopic yeast-like bodies, has round-oval spores measuring 4-12 $\mu \mathrm{m}$ in the gelatinous reaction type and 2-4 $\mu \mathrm{m}$ in the granulomatous reaction type, and has a characteristic mucicarmine-positive mucinous capsule and produces a single buds (Beltrame et al., 2017; Grayson \& Colonje, 2020; Hinshaw \& Longley, 2015). Sporotrichosis caused by S. schenckii will appear as round-oval spores with a diameter of 4$6 \mu \mathrm{m}$, and the staining is more polished on the periphery, with single or multiple buds. However, small cigar-shaped bodies with a length of $<8 \mu \mathrm{m}$ can also be seen (Grayson \& Colonje, 2020; Hinshaw \& Longley, 2015). Chromoblastomycosis with histologic features of characteristic sclerotic cells, or Medlar bodies, and the appearance of spherical oval or spherical spores, measuring 6-12 $\mu \mathrm{m}$ ("copper pennies"), dark brown, thick-walled, singly or in clusters or chains, found in giant cells in the 
dermis and extracellularly (Hinshaw \& Longley, 2015; Papadavid et al., 2012). Paracoccidioidomycosis/South American Blastomycosis caused by Paracoccidioides brasiliensis has single spores 6-20 $\mu \mathrm{m}$ in diameter in tissue with narrow-based buds (pilot's wheel) or without buds. In rare spores with multiple buds (60 $\mu \mathrm{m}$ diameter), numerous peripheral buds are seen which are arranged and protruded on the surface of a ball-shaped fungus cell (marine pilot's wheel appearance) (Grayson \& Colonje, 2020; Hinshaw \& Longley, 2015). African histoplasmosis caused by H.capsulatum var. duboisii has a uniform cell size with a diameter of 8-15 $\mu \mathrm{m}$, with relatively thick walls and often a single appearance. Large blastoconidia attach to stem cells through a thin neck (Beltrame et al., 2017; Hinshaw \& Longley, 2015).

Lobomycosis generally takes a long time to diagnose. In its management, early-stage treatment and treatment of a single lesion with excision can provide a good prognosis (Arju et al., 2014; de Sousa et al., 2015). The best management of localized lesions is excision, (Hay, 2020) with wide margins, or cryotherapy can be performed (Queiroz-Telles et al., 2017). In the Florian study, 2020, it was stated that Kaiabi tribal patients in Brazil with localized lesions who received surgical treatment showed no recurrence in 30 years of observation (Florian et al., 2020). Treatment can be in the form of giving clofazimine or clofazimine together with itraconazole, (Hall et al., 2017) although until now, there is no antimycotic that is effective (Arenas et al., 2019). The Pasqualotto study, AC., 2021, reported that chronic renal failure patients who had undergone hemodialysis with extensive lobomycosis with extensive clinical manifestations of keloidal-like lesions showed a good response to the use of posaconazole, and it is hoped that long-term therapy can give better results (Pasqualotto et al., 2021).

The prognosis of this disease is poor with slow chronic progression. Bhawan et al., 1976 in Arju, R. 2014 stated that there is an effect of melanin in fungal cell walls on the ability of macrophages to phagocytize and the progression of this disease (Arju et al., 2014). Lobomycosis with ulceration or secondary infection can affect the quality of life of the sufferer. Long-term complications of lobomycosis infection can lead to squamous cell carcinoma (Beltrame et al., 2017; Grayson \& Colonje, 2020). Nogueira, 2013 reported a case of squamous cell carcinoma associated with lobomycosis based on clinical findings and histopathological features (Nogueira et al., 2013).

\section{Conclusion}

The lobomycosis cases is unique and rarely reported because of uncommonly experienced in people living in nonendemic areas, however, it is possible that this infection can be found anywhere. This case quite challenging due to complicated clinical findings and long-term use of corticosteroids might become one of risk factor. Histopathological examination, especially with special stains, can help to distinguish this fungal infection from other possible infections. For those reason, clinicopathological correlation with a highly experienced in pathology field will support for establishing the diagnosis of Lobomycosis infections.

\section{References}

Araújo, M. G., dos Santos, S. N. M. B., Guedes, A. C. M., Cirilo, N. S., \& Aguilar, C. R. (2018). Lobomycosis: A therapeutic challenge. Anais Brasileiros de Dermatologia, 93(2), 279-281. https://doi.org/10.1590/abd1806-4841.20187044

Arenas, C. M., Rodriguez-Toro, G., Ortiz-Florez, A., \& Serrato, I. (2019). Lobomycosis in soldiers, Colombia. Emerging Infectious Diseases, 25(4), 654-660. https://doi.org/10.3201/eid2504.181403

Arju, R., Abraham, S., Kothadia, J. P., Kaminski, M., \& Giashuddin, S. (2014). Jorge Lobo's disease: A case of keloidal blastomycosis (lobomycosis) in a nonendemic area. Therapeutic Advances in Infectious Disease, 2(4), 91-96. https://doi.org/10.1177/2049936114559919

Beltrame, A., Danesi, P., Farina, C., Orza, P., Perandin, F., Zanardello, C., Rodari, P., Staffolani, S., \& Bisoffi, Z. (2017). Case report: Molecular confirmation of lobomycosis in an Italian traveler acquired in the Amazon Region of Venezuela. American Journal of Tropical Medicine and Hygiene, 97(6), 1757-1760. https://doi.org/10.4269/ajtmh.17-0446

Carvalho, K. A. de, Enokihara, M. M. S. e S., Floriano, M. C., \& Mascarenhas, M. R. M. (2015). Jorge Lobo's disease. Anais Brasileiros de Dermatologia, 90(4), 586-588. https://doi.org/10.1590/abd1806-4841.20153603 
de Sousa, P. P., Schettini, A. P. M., Rodrigues, C. A. C., \& Westphal, D. C. (2015). Lacaziosis - unusual clinical presentation. Anais Brasileiros de Dermatologia, 90(2), 268-269. https://doi.org/10.1590/abd1806-4841.20153430

Florian, M. C., Rodrigues, D. A., de Mendonça, S. B. M., Colombo, A. L., \& Tomimori, J. (2020). Epidemiologic and clinical progression of lobomycosis among Kaiabi Indians, Brazil, 1965-2019. Emerging Infectious Diseases, 26(5), 430-436. https://doi.org/10.3201/eid2605.190958

Francesconi, V. A., Klein, A. P., Santos, A. P. B. G., Ramasawmy, R., \& Francesconi, F. (2014). Lobomycosis: Epidemiology, clinical presentation, and management options. Therapeutics and Clinical Risk Management, 10, 851-860. https://doi.org/10.2147/TCRM.S46251

Grayson, W., \& Colonje, E. (2020). Infectious Diseases of the Skin. In E. Calonje, T. Brenn, A. J. Lazar, \& S. D. Billings (Eds.), McKee's Pathology of the Skin with Clinical Correlations (5th ed.). 962-964. Elsevier.

Hall, B. J., Cockerell, C. J., Chisholm, C., Jessup, C., Vandergriff, T., Motaprthi, K., \& Elston, D. M. (2017). Lobomycosis. In Diagnostic Pathology Nonneoplastic Dermatopathology (2nd ed.), 644-645. Elsevier Inc.

Hay, R. J. (2020). Subcutaneous Mycoses: General Principles. In E. T. Ryan, D. R. Hill, T. Solomon, N. E. Aronson, \& T. P. Endy (Eds.), Hunter's Tropical Medicine and Emerging Infectious Diseases (10th ed.), 658. Elsevier Inc.

Hinshaw, M. A., \& Longley, B. J. (2015). Fungal Diseases. In D. E. Elder, R. Elenitsas, M. Rosebach, G. F. Murphy, A. I. Rubin, \& X. Xu (Eds.), Lever's Histopathology of The Skin (11th ed.). Wolters Kluwer.

Kanashiro-Galo, L., Alexandre, A. F., Tafuri, W. L., Barboza, T. C., Quaresma, J. A. S., de Brito, A. C., do Nascimento, G. Y. F. da S., Filho, A. M. dos S., Sotto, M. N., \& Pagliari, C. (2020). Lacaziosis: immunohistochemical evaluation of elements of the humoral response in cutaneous lesions. Rev Inst Med Trop São Paulo, 62(75), 1-5. https://doi.org/10.1177/016555157900100507

Nogueira, L., Mendes, L., Rodrigues, C. A. C., Santos, M., Talhari, S., \& Talhari, C. (2013). Lobomycosis and squamous cell carcinoma. Anais Brasileiros de Dermatologia, 88(2), 293-295. https://doi.org/10.1590/s0365-05962013000200024

Oliveira, F. da S., Lopes, N. P., Talhari, C., \& Schettini, A. (2020). Case for diagnosis. Keloidal cord-like lesion on the leg. Anais Brasileiros de Dermatologia, 95(3), 386-389. https://doi.org/10.1016/j.abd.2019.07.008

Papadavid, E., Dalamaga, M., Kapniari, I., Pantelidaki, E., Papageorgiou, S., Pappa, V., Tsirigotis, P., Dervenoulas, I., Stavrianeas, N., \& Rigopoulos, D. (2012). Lobomycosis: A case from southeastern europe and review of the literature. Journal of Dermatological Case Reports, 6(3), 65-69. https://doi.org/10.3315/jdcr.2012.1104

Pasqualotto, A. C., Jaskulski Filho, S. D., de Sena, M. G., dos Santos, A. F., \& Severo, M. M. S. (2021). Posaconazole for lobomycosis. Brazilian Journal of Infectious Diseases, 25(2), 4-5. https://doi.org/10.1016/j.bjid.2021.101576

Patterson, J. W. (2013). Infectious Diseases, Including Infestations and Parasitic Diseases. In K. O. Leslie \& M. R. Wick (Eds.), Practical Skin Pathology A Diagnostic Approach. Elsevier Saunders.

Pereira, A. S. et al. (2018). Metodologia da pesquisa científica. UFSM.

Plaza, J. A., \& Prieto, V. G. (2012). Infectious Diseases of the Skin. In S. Suster (Ed.), Inflammatory skin disorders (p. 219). Demos Medical. https://doi.org/10.1054/cdip.2001.0100

Queiroz-Telles, F., Fahal, A. H., Falci, D. R., Caceres, D. H., Chiller, T., \& Pasqualotto, A. C. (2017). Neglected endemic mycoses. The Lancet Infectious Diseases, 17(11), 1-11. https://doi.org/10.1016/S1473-3099(17)30306-7

Yin, R. K. (2017). Case study. Canada: Sage Publications. 